\title{
SNAKE ENVENOMATIONS IN NORTHWEST COUNTIES OF THE RIO DE JANEIRO STATE, BRAZIL
}

TINOCO H. B.(1), NORBERG A. N. (2), PILE E. (2), CARVALHO C. R. P. (2), SILVA D. A.(2), GUERRA-SANCHES F.(2)

(1) Campos dos Goitacases Faculty of Dentistry, Rio de Janeiro, Brazil; (2) Iguaçu University-UNIG, Rio de Janeiro, Brazil

ABSTRACT: The frequency of envenoming in Northwest counties of the Rio de Janeiro State, Brazil, from 1995 to 2000 was evaluated. Reports from the Municipal Secretariat of Health of these counties were used. The results demonstrated that, from 1997 to 1999, there was a shortage of notification, and 40 cases of envenomations caused by Bothrops snakes were registered. These cases were more common from February to October, and the lower limbs of male peasants were the mainly affected areas.

KEY WORDS: poisonous snakes, Bothrops, envenomations, Rio de Janeiro, Brazil

\section{CORRESPONDENCE TO:}

A. N. NORBERG, Avenida Abílio Augusto Távora, 2134, 26260-000, Nova Iguaçu, RJ. Email: norberg@uol.com.br 


\section{INTRODUCTION}

According to the World Health Organization - WHO (10), snakes, among the poisonous animals, are the main responsible for envenomings, mainly in the Southeast of Asia and Tropical America. The frequency of envenomations in Brazil became a problem of public health, and the reports carried out in the states of São Paulo, Minas Gerais, and Rio Grande do Sul showed Bothrops snakes as cause of $90 \%$ of the cases (4). However, we focused on the several Bothrops species wide distribution over the Rio de Janeiro State $(2,7)$. Based on this information, the present survey aims to evaluate the cases reported in some Northwest counties of the Rio de Janeiro State, Brazil.

\section{MATERIAL AND METHODS}

We analyzed the envenomations reports from the Municipal Secretariat of Health of Bom Jesus do Itabapoana, Italva, Varre-sai, Cardoso Moreira, Itaperuna, Laje do Muriaé, Natividade, Porciúncula, and São José de Ubá between 1995 and 2000. Sex, profession, and injured area of the people involved; month of the accident; and the snake's species were statistically evaluated (Student test; $p<0.05$ ).

\section{RESULTS}

Forty cases were reported in 1995, 1996 and 2000, all caused by Bothrops snakes (Table 1). Envenomations were more frequently reported in hot months (from February to May), mainly in 1995. It was also verified that the envenomings affected mainly the lower limbs of male peasants from 11 to 40 years old (Tables 2 and 3).

Table 1: Frequency of envenomations by Bothrops snakes in Northwest counties of the Rio de Janeiro State, Brazil, in 1995, 1996 and 2000

\begin{tabular}{|c|c|c|c|c|c|c|c|c|c|c|c|c|c|}
\hline \multirow[b]{2}{*}{ Year } & \multicolumn{13}{|c|}{ Months } \\
\hline & Jan & Feb & Mar & Apr & May & Jun & Jul & Aug & Sept & Oct & Nov & Dec & Total \\
\hline 1995 & 0 & 1 & 6 & 1 & 4 & 1 & 1 & 2 & 2 & 3 & 1 & 1 & $\begin{array}{c}23 \\
(57.5 \%)\end{array}$ \\
\hline 1996 & 0 & 2 & 1 & 2 & 1 & 0 & 0 & 0 & 0 & 0 & 0 & 0 & $\begin{array}{c}6 \\
(15 \%)\end{array}$ \\
\hline 2000 & 0 & 0 & 1 & 2 & 0 & 3 & 3 & 1 & 0 & 0 & 0 & 1 & $\begin{array}{c}11 \\
(27.5 \%)\end{array}$ \\
\hline Total & $\begin{array}{c}0 \\
(0 \%)\end{array}$ & $\begin{array}{c}3 \\
(7.5 \%) \\
\end{array}$ & $\begin{array}{c}8 \\
(20 \%) \\
\end{array}$ & $\begin{array}{c}5 \\
(12.5 \%) \\
\end{array}$ & $\begin{array}{c}5 \\
(12.5 \%) \\
\end{array}$ & $\begin{array}{c}4 \\
(10 \%) \\
\end{array}$ & $\begin{array}{c}4 \\
(10 \%)\end{array}$ & $\begin{array}{c}3 \\
(7.5 \%) \\
\end{array}$ & $\begin{array}{c}2 \\
(5 \%) \\
\end{array}$ & $\begin{array}{c}3 \\
(7.5 \%) \\
\end{array}$ & $\begin{array}{c}1 \\
(2.5 \%) \\
\end{array}$ & $\begin{array}{c}2 \\
(5 \%)\end{array}$ & $\begin{array}{c}40 \\
(100 \%) \\
\end{array}$ \\
\hline
\end{tabular}


Table 2: Frequency of envenomations in Northwest counties of the Rio de Janeiro State, Brazil, in 1995, 1996 and 2000, according to age range and sex

\begin{tabular}{c|ccc}
\hline & \multicolumn{3}{|c}{ Sex } \\
\hline Age range & Male & Female & Total \\
\hline $1-10$ & $0(0 \%)$ & $0(0 \%)$ & $0(0 \%)$ \\
$11-20$ & $9(26.5 \%)$ & $0(0 \%)$ & $9(22.5 \%)$ \\
$21-30$ & $8(23.5 \%)$ & $1(16.7 \%)$ & $9(22.5 \%)$ \\
$31-40$ & $8(23.5 \%)$ & $3(5 \%)$ & $11(27.5 \%)$ \\
$41-50$ & $6(17.6 \%)$ & $2(33.3 \%)$ & $8(20 \%)$ \\
$51-60$ & $2(5.9 \%)$ & $0(0 \%)$ & $2(5 \%)$ \\
$>60$ & $1(2.9 \%)$ & $0(0 \%)$ & $1(2.5 \%)$ \\
Total & 34 & 6 & 40 \\
\hline
\end{tabular}

Significant difference was not verified (Hotelling test; $p>0.05$ )

Table 3: Frequency of envenomations in the Northwest counties of the Rio de Janeiro State, Brazil, in 1995, 1996 and 2000, according to profession and injured anatomical area

\begin{tabular}{|c|c|c|c|c|c|c|}
\hline & \multicolumn{6}{|c|}{ Bitten area } \\
\hline Professions & Foot & Legs & $\begin{array}{l}\text { Foot } \\
\text { finger }\end{array}$ & $\begin{array}{l}\text { Hand } \\
\text { finger }\end{array}$ & $\begin{array}{l}\text { Trunk, } \\
\text { hand and } \\
\text { ankles }\end{array}$ & Total \\
\hline Peasants & 21 & 6 & 1 & 3 & 2 & $\begin{array}{l}33^{\mathrm{a}} \\
(82.5 \%)\end{array}$ \\
\hline Other professions & 4 & 0 & 2 & 0 & 1 & $\begin{array}{l}7^{b} \\
(17.5 \%)\end{array}$ \\
\hline Total & $\begin{array}{l}25 \\
(62.5 \%)\end{array}$ & $\begin{array}{l}6 \\
(15 \%)\end{array}$ & $\begin{array}{l}3 \\
(7.5 \%)\end{array}$ & $\begin{array}{l}3 \\
(7.5 \%)\end{array}$ & $\begin{array}{l}3 \\
(7.5 \%)\end{array}$ & $\begin{array}{l}40 \\
(100 \%)\end{array}$ \\
\hline
\end{tabular}

$\mathrm{a}>\mathrm{b}$; (Student test; $\mathrm{p}<0.05$ ) 


\section{DISCUSSION}

Envenomations were related to the distribution of the genus in areas occupied by the Atlantic forest, corroborating the reports of Barroso et al. (3). However, there was a shortage of notification from 1997 to 1999, what means that the real situation is unknown. Lack of notification was previously verified by Sales et al. (9) in Nova Iguaçu and Queimados counties. According to Barraviera (1), a shortage is consequence of a communication flaw between the doctor and the patient, caused by deficient campaigns, mainly in the rural area (5). We also believe that notifications of envenomation during the treatment with anti-ophidian serum stocked in health units are not conclusive for a real evaluation of the number of cases, because several rural leaders acquire the medication in pharmacies. Results of the evaluated variables and the reported genus (Tables 1, 2 and 3) also corroborated the reports of Puorto et al. (8) and Guimarães (6). It is important to highlight that Puorto et al. (8) also cited Bothrops jararaca as the main responsible for envenomations in urban areas, showing the species adaptability to environmental changes.

\section{REFERENCES}

1 BARRAVIERA B. Estudo clínico dos acidentes ofídicos- Revisão. J. Bras. Med., 1993, 65, 209-50.

2 BARRAVIERA B., PEREIRA PCM.. Acidentes por serpentes do gênero Bothrops, Lachesis e Micrurus. Arq. Bras. Med., 1997, 65, 345-55.

3 BARROSO RD. Ofidismo no Brasil: considerações em torno de 2238 acidentes ofídicos tratados com soro. Bol. Inst. Vital Brasil, 1944, 26, 35-47.

4 CARDOSO JLC., BRANDO RB. Acidentes por animais peçonhentos: clínica e tratamento. São Paulo: Santos, 1982: 102-8.

5 CARVALHO CRP., PICCININI RS. Uso de botas de borracha como prevenção aos acidentes por Crotalus durissus (LAURENTIS, 1768). Rev. Ciênc. Biol. Saúde, 2000, 1, 95-7.

6 GUIMARÃES LA. Acidentes por serpentes peçonhentas do Brasil. Rev. Assoc. Med. Bras., 1989, 36, 66-77.

7 HOGE AR., ROMANO-HOGE SA. Sinopse das serpentes peçonhentas do Brasil. Mem. Inst. Butantan, 1979, 36, 109-207. 
8 PUORTO J., SAZIMA I., LAPORTA-FERREIRA IL. Serpentes da região urbana de São Paulo. In: CONGRESSO BRASILEIRO ZOOLOGIA, 17, Londrina, 1990. Resumos...Londrina: Sociedade Brasileira de Zoologia, 1990. 442.

9 SALES MSN., SILVA CC., GUIMARÃES RR., COELHO VM.. Levantamento de casos de acidentes por animais peçonhentos nos municípios de Nova Iguaçu e Queimados - RJ. Rev. Ciênc. Biol. Saúde., 2000, 1, 43-53.

10 WORLD HEALTH ORGANIZATION. Progress in the characterization of venoms and standardization of antivenins. Geneva: W.H.O. (WHO offset publication), 1981, p.44. 